\begin{tabular}{|l|l|l||}
\hline \multicolumn{2}{|c|}{ PublisherInfo } \\
\hline \hline PublisherName & $:$ & BioMed Central \\
\hline \hline PublisherLocation & $:$ & London \\
\hline \hline PublisherImprintName & $:$ & BioMed Central \\
\hline \hline
\end{tabular}

\title{
Articles selected by Faculty of 1000: functional genomics of Bardet-Biedl syndrome; sumo proteomics; phosphopeptide arrays; plant phosphoproteomics; novel antibiotic resistance genes
}

\begin{tabular}{|c|c|}
\hline \multicolumn{2}{|c|}{ Articlelnfo } \\
\hline ArticlelD & 3497 \\
\hline ArticleDOI & 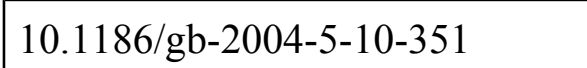 \\
\hline ArticleCitationID & 351 \\
\hline ArticleSequenceNumber & 22 \\
\hline ArticleCategory & \begin{tabular}{|l|} 
Paper report \\
\end{tabular} \\
\hline ArticleFirstPage & 1 \\
\hline ArticleLastPage & 3 \\
\hline ArticleHistory & \begin{tabular}{|lrl} 
RegistrationDate & $:$ & $2004-9-23$ \\
OnlineDate & $:$ & $2004-9-23$
\end{tabular} \\
\hline
\end{tabular}




\begin{tabular}{|l|l|l||}
\hline ArticleCopyright & $:$ & BioMed Central Ltd2004 \\
\hline \hline ArticleGrants & $:$ & \\
\hline \hline ArticleContext & $:$ & 13059551010 \\
\hline
\end{tabular}

\section{Functional genomics of Bardet-Biedl syndrome}

A selection of evaluations from Faculty of $\mathbf{1 0 0 0}$ covering the functional genomics of Bardet-Biedl syndrome; sumo proteomics; phosphopeptide arrays; plant phosphoproteomics; novel antibiotic resistance genes.

Comparative genomic analysis identifies an ADP-ribosylation factor-like gene as the cause of Bardet-Biedl syndrome (BBS3). Chiang AP, Nishimura D, Searby C, Elbedour K, Carmi R, Ferguson AL, Secrist J, Braun T, Casavant T, Stone EM, Sheffield VC. Am J Hum Genet 2004, 75:475-484.

For the Faculty of 1000 evaluation of this article please see: http://genomebiology.com/reports/F1000/ gb-2004-5-10-351.asp\#Chiang

\section{Sumo proteomics}

Global analysis of protein sumoylation in Saccharomyces cerevisiae . Wohlschlegel JA, Johnson ES, Reed SI, Yates JR. J Biol Chem 2004, Aug 23.

For the Faculty of 1000 evaluation of this article please see: http://genomebiology.com/reports/F1000/ gb-2004-5-10-351.asp\#Wohlschlegel

\section{Phosphopeptide arrays}

High-content peptide microarrays for deciphering kinase specificity and biology. Schutkowski M, Reimer U, ..., Alessi DR, Schneider-Mergener J. Angew Chem Int Ed Engl 2004, 43:2671-2674.

For the Faculty of 1000 evaluation of this article please see: http://genomebiology.com/reports/F1000/ gb-2004-5-10-351.asp\#Schutkowski 


\section{Plant phosphoproteomics}

Phosphoproteomics of the Arabidopsis plasma membrane and a new phosphorylation site database. Nühse TS, Stensballe A, Jensen ON, Peck SC. Plant Cell 2004, 16:2934-2405.

For the Faculty of 1000 evaluation of this article please see: http://genomebiology.com/reports/F1000/ gb-2004-5-10-351.asp\#Nuhse

\section{Novel antibiotic resistance genes}

Uncultured soil bacteria are a reservoir of new antibiotic resistance genes. Riesenfeld CS, Goodman RM, Handelsman J. Environ Microbiol 2004, 6:981-989.

For the Faculty of 1000 evaluation of this article please see: http://genomebiology.com/reports/F1000/ gb-2004-5-10-351.asp\#Riesenfeld 